\title{
The Phylogenetic Position of Helicobacter nemestrinae
}

\author{
LINDSAY I. SLY, ${ }^{1}$ MELINDA A. BRONSDON, ${ }^{2}$ JOHN P. BOWMAN, ${ }^{1}$ ANDREW HOLMES, ${ }^{1}$ \\ AND ERKO STACKEBRANDT ${ }^{1 *}$ \\ Department of Microbiology, Centre for Bacterial Diversity and Identification, The University of Queensland, \\ St. Lucia, Queensland 4072, Australia, ${ }^{1}$ and Regional Primate Research Center, \\ University of Washington, Seattle, Washington $98195^{2}$
}

\begin{abstract}
Comparison of the Helicobacter nemestrinae 16S ribosomal DNA with published homologous sequences from members of the genera Helicobacter, Wolinella, and Campylobacter reveals a close relationship between $\boldsymbol{H}$. nemestrinae, $H$. pylori, and $H$. acinonyx. This finding is unexpected since these species differ significantly in their DNA guanine-plus-cytosine contents ( 24 to 38 mol\%).
\end{abstract}

Recently, a spiral, gram-negative bacterium from the gastric mucosa of a macaque monkey was described as Helicobacter nemestrinae (1). This organism phenotypically resembled Helicobacter pylori and other members of the genus Helicobacter but showed little overall DNA similarity to certain members of this genus, including $H$. pylori $(<10 \%)$ and $H$. mustelae $(<1 \%)$. The low DNA base composition of $24 \mathrm{~mol} \%$ guanine plus cytosine $(\mathrm{G}+\mathrm{C})$ made the inclusion of $H$. nemestrinae in the genus Helicobacter uncertain. To establish the phylogenetic position of $H$. nemestrinae ATCC $49396^{\mathrm{T}}$ ( $\mathrm{T}=$ type strain), we have undertaken a sequence analysis of its $16 \mathrm{~S}$ ribosomal DNA. The nearly complete sequence (EMBL accession number X67854), derived by direct sequence analysis of polymerase chain reaction-mediated amplification products (8), covered the region between positions 11 and 1498 of the homologous Escherichia coli sequence (2). The sequence was aligned with the sequences of members of the Campylobacter branch (7), including $H$. pylori ATCC $43504^{\mathrm{T}}$ (GenBank accession number M86748), Helicobacter acinonyx 90-119-3 (M88148), Helicobacter felis Lee DS3 (M37643), Helicobacter muridarum ATCC $49282^{\text {T }}$ (M80205), Helicobacter mustelae ATCC 43774 (M35048), "Flexispira rappini” NADC 1937 (M88137), Helicobacter cinaedi (no strain number indicated) (M88151), Helicobacter fennelliae CCUG 18820 (M88154), Wolinella succinogenes ATCC 29543 (M88159), and Campylobacter hyointestinalis ATCC 35217 (M65010). The following regions of alignment uncertainty and missing sequence information were omitted prior to the analysis: positions 1 to 5,77 to 90,151 to 158,176 to 203,304 to 362,702 to 760,940 to 953,964 to 971,1301 to 1360 , and 1490 to 1542 (E. coli nomenclature [2]).

Phylogenetically, $H$. nemestrinae, like other members of the genus Helicobacter (5), is a member of the Campylobacter branch (7). The dendrogram of relationship (Fig. 1), which is based on evolutionary distance values (Table 1, lower left) and sequence similarity values (Table 1 , upper right), shows that $H$. nemestrinae, $H$. pylori, and $H$. acinonyx form a group of closely related species ( 94.5 to $95.9 \%$ sequence similarity in the regions compared). The isolated position of $H$. nemestrinae within this cluster confirms its species status. $H$. felis appears to be a member of a sister group, showing 93.0 to $94.9 \%$ sequence similarity, while the other members of this genus (including " $F$. rappini") are more distantly related ( 90.8 to $94.6 \%$ sequence similarity) (see reference 5 for the relationship between helicobacters and campylobacters).

\footnotetext{
* Corresponding author.
}

The rather long internode separating the more deeply branching helicobacters from the $H$. felis- $H$. nemestrinae group, together with the comparatively longer branch lengths leading to these species, could be interpreted as the result of a significant change in nucleotide substitutions in the ribosomal DNA genes that began after the latter group separated from the ancestor that also gave rise to $H$. muridarum. Support for more rapid evolution of certain members of the genus Helicobacter is detectable in Table 1. Apparently, rapidly evolving organisms exhibit lower similarity values than other organisms with outside reference organisms (in this case $W$. succinogenes and $C$. hyointestinalis) (9). The effect is least clearly expressed in $H$. pylori, which also has a rather short branch length. Other examples of rapidly evolving members of the domain Bacteria are found in the taxa Mycoplasma (11), Bacillus (9), Planctomycetales, and Chlamydia $(6,10)$. The long branch lengths of $H$. nemestrinae and its closest relatives do not seem to be the result of selective pressure for the nucleotide content of the rRNA genes since the $\mathrm{G}+\mathrm{C}$ contents of the rRNA genes of all of the organisms shown in Fig. 1 fall in a narrow range ( 49 to $51.0 \mathrm{~mol} \%$ ). However, at the overall genomic level the accelerated mutation rate of $H$. nemestrinae and its two relatives is detectable by the changes in the base composition of the DNA. While the more deeply branching members of the genus exhibit a rather narrow range of 35 to $38 \mathrm{~mol} \%$ $\mathrm{G}+\mathrm{C}$, the more recently evolved members have a signifi-

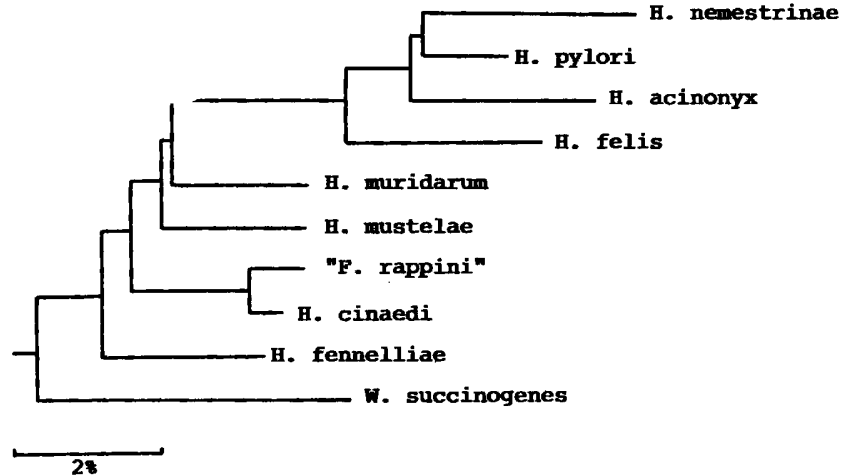

FIG. 1. Dendrogram of relationships for $H$. nemestrinae and other representatives of the genus Helicobacter generated by using the algorithm of De Soete (3) and the sequence dissimilarity values shown in Table 1. C. hyointestinalis (as a relative of helicobacters) was used to place the root. Bar $=2 \%$ sequence divergence. 
TABLE 1. Evolutionary distances and similarity values in the regions compared for the $16 \mathrm{~S}$ rRNAs of $H$. nemestrinae, various representatives of the genus Helicobacter, $W$. succinogenes, and $C$. hyointestinalis

\begin{tabular}{|c|c|c|c|c|c|c|c|c|c|c|c|}
\hline \multirow[b]{2}{*}{ Species } & \multicolumn{11}{|c|}{ Evolutionary distance or similarity value $(\%)^{a}$} \\
\hline & $\begin{array}{l}\text { H. neme- } \\
\text { strinae }\end{array}$ & H. pylori & H. acinonyx & H. felis & $\begin{array}{l}\text { H. muri- } \\
\text { darum }\end{array}$ & H. mustelae & "F. rappini" & H. cinaedi & $\begin{array}{l}\text { H. fennel- } \\
\text { liae }\end{array}$ & $\begin{array}{l}\text { W. succino- } \\
\text { genes }\end{array}$ & $\begin{array}{l}\text { C. hyointest- } \\
\text { inalis }\end{array}$ \\
\hline H. nemestrinae & & 95.9 & 94.5 & 93.0 & 92.8 & 92.1 & 91.4 & 91.2 & 90.8 & 89.2 & 82.5 \\
\hline H. pylori & 4.3 & & 95.9 & 94.9 & 94.6 & 93.9 & 93.2 & 92.8 & 92.9 & 91.0 & 83.8 \\
\hline H. acinonyx & 5.7 & 4.3 & & 94.4 & 93.1 & 92.5 & 91.9 & 91.8 & 91.3 & 89.7 & 82.0 \\
\hline H. felis & 6.7 & 5.2 & 5.6 & & 93.5 & 93.3 & 92.6 & 92.6 & 93.3 & 90.4 & 82.9 \\
\hline H. muridarum & 8.3 & 6.6 & 7.8 & 7.7 & & 97.0 & 96.3 & 96.2 & 95.4 & 93.5 & 84.7 \\
\hline H. mustelae & 8.3 & 6.5 & 7.5 & 7.2 & 3.6 & & 95.4 & 95.0 & 94.0 & 93.6 & 84.3 \\
\hline "F. rappini" & 9.1 & 7.5 & 8.6 & 7.9 & 4.2 & 4.4 & & 99.1 & 93.3 & 92.6 & 85.3 \\
\hline H. cinaedi & 9.4 & 7.9 & 8.6 & 8.1 & 4.2 & 4.7 & 1.2 & & 95.8 & 92.5 & 85.0 \\
\hline H. fennelliae & 9.6 & 7.5 & 9.1 & 7.3 & 4.9 & 5.8 & 4.7 & 4.3 & & 92.6 & 84.5 \\
\hline W. succinogenes & 12.6 & 10.5 & 11.4 & 11.0 & 6.9 & 6.9 & 7.4 & 7.8 & 7.5 & & 84.2 \\
\hline C. hyointestinalis & 20.6 & 19.8 & 21.6 & 20.3 & 18.9 & 18.6 & 17.5 & 17.9 & 17.1 & 18.6 & \\
\hline
\end{tabular}

${ }^{a}$ The values on the lower left are evolutionary distances, which were calculated as described by Jukes and Cantor (4). The values on the upper right are similarity values. See text for the regions compared.

cantly wider range $(24 \mathrm{~mol} \% \mathrm{G}+\mathrm{C}$ for $H$. nemestrinae, 30 mol\% $\mathrm{G}+\mathrm{C}$ for $H$. acinonyx, 36 to $38 \mathrm{~mol} \% \mathrm{G}+\mathrm{C}$ for $H$. pylori, and $42.5 \mathrm{~mol} \% \mathrm{G}+\mathrm{C}$ for $H$. felis). The range of 18.5 $\mathrm{mol} \% \mathrm{G}+\mathrm{C}$ is rather high for members of a genus that consists of aerobic bacteria, and it reinforces the neccessity to circumscribe taxa by a polyphasic approach (7). Whether the change in the substitution rate of DNA is connected with the invasion of novel hosts will remain an open question until phylogenetic data on additional semantides or from more representatives of the genus Helicobacter isolated from the hosts become available.

We thank William Weisburg, GenTrak, Framingham, Mass., for kindly providing us with the accession numbers of the 16S rRNA sequences.

This study was supported by the National Health and Medical Research Council, Australia (E.S.), by a University of Queensland Special Project Grant (to L.I.S. and E.S.), and by grant RR00166 from the National Institutes of Health to the Regional Primate Research Center (M.A.B.).

\section{REFERENCES}

1. Bronsdon, M. A., C. S. Goodwin, L. I. Sly, T. Chilvers, and F. D. Schoenknecht. 1991. Helicobacter nemestrinae sp. nov., a spiral bacterium found in the stomach of a pigtailed macaque (Macaca nemestrina). Int. J. Syst. Bacteriol. 41:148-153.

2. Brosius, J., J. J. Palmer, J. P. Kennedy, and H. F. Noller. 1978. Complete nucleotide sequence of a 16 S ribosomal RNA gene from Escherichia coli. Proc. Natl. Acad. Sci. USA 75:48014805.

3. De Soete, G. 1983. A least squares algorithm for fitting additive trees to proximity data. Psychometrika 48:621-626.
4. Jukes, T. H., and C. R. Cantor. 1969. Evolution of protein molecules, p. 21-132. In N. H. Munro (ed.), Mammalian protein metabolism. Academic Press, New York.

5. Lee, A., M. W. Philipps, J. L. O'Rourke, B. J. Paster, F. E. Dewhirst, G. J. Fraser, J. G. Fox, L. I. Sly, P. J. Romaniuk, T. J. Trust, and S. Koupracht. 1992. Helicobacter muridarum sp. nov., a microaerophilic helical bacterium with a novel ultrastructure isolated from the intestinal mucosa of rodents. Int. J. Syst. Bacteriol. 42:27-36.

6. Liesack, W., R. Söller, T. Stewart, H. Haas, S. Giovannoni, and E. Stackebrandt. 1992. The influence of tachytelically evolving sequences on the topology of phylogenetic trees-intrafamily relationships and the phylogenetic position of Planctomycetaceae as revealed by comparative analysis of $16 \mathrm{~S}$ ribosomal RNA sequences. Syst. Appl. Microbiol. 15:357-362.

7. Stackebrandt, E. 1991. Unifying phylogeny and phenotypic diversity, p. 19-47. In A. Balows, H. G. Trüper, M. Dworkin, W. Harder, and K. H. Schleifer (ed.), The prokaryotes. A handbook of the biology of bacteria: ecophysiology, isolation, identification and applications. Springer Verlag, New York.

8. Stackebrandt, E., and W. Liesack. 1992. The potential of rDNA in identification and diagnostics, p. 232-239. In C. Kessler (ed.), Nonradioactive labelling and detection of biomolecules. Springer-Verlag, Berlin.

9. Stackebrandt, E., and C. R. Woese. 1981. The evolution of prokaryotes. Symp. Soc. Gen. Microbiol. 32:1-31.

10. Weisburg, W. G., T. P. Hatch, and C. R. Woese. 1986. Eubacterial origin of the chlamydiae. J. Bacteriol. 167:570-574.

11. Weisburg, W. G., J. G. Tully, D. L. Rose, J. P. Petzel, H. Oyaizu, D. Yang, L. Mandelco, J. Sechrest, T. G. Lawrence, J. Van Etten, J. Maniloff, and C. R. Woese. 1989. A phylogenetic analysis of the mycoplasmas: basis for their classification. J. Bacteriol. 171:6455-6467. 